\title{
「医学用語シソーラス」と索引作業
}

\section{"Thesaurus for Medical and Health Related Terms" and it's application for indexing}

浜田 雅美 ${ }^{1}$ | 佐久間 せつ子 ${ }^{1} \mid$ 三沢 一成 ${ }^{1}$

\section{HAMADA Masami'; SAKUMA Setsuko'; MISAWA Kazunari'}

1 特定非営利活動法人 医学中央雑誌刊行会（干168-0072 東京都杉並区高井戸東2-5-18)

Tel : 03-3334-7575 FAX: 03-3334-0497 E-mail : hamada-m@jamas.or.jp

1 Japan Medical Abstracts Society (2-5-18 Takaido-higashi Suginami-ku, Tokyo 168-0072)

\section{1.はじめに}

医学中央雑誌刊行会（以下，当会）は，国内医 学文献の二次資料である『医学中央雑誌』を1903 年に発刊し，以来，抄録・索引誌として冊子体を 刊行してきた。1983年にコンピュータ編集を開始 することで, 『医学中央雑誌』の内容を電子データ として保有できるようになったことを契機に, 1992年に「医中誌CD-ROM」版を発行し，さらに 2000年からは，インターネットを介した検索サー ビス「医中誌Web」を提供するようになった。「医 中誌Web」には, 1983年以降の作成デー夕を収録 している。対象とする分野は, 医学に加えて, 歯 学, 薬学, 看護学, 獣医学, およびその関連領域 であり,それらの定期刊行物を網羅的に収集し，書 誌事項, 抄録, 索引等からなる文献情報を提供し ている1)。

「医中誌Web」において，適切で効率的な検索を するために，特に大きな役割を果たすのが，索引 である。当会では専門の索引者が, 実際に個々の 文献に目を通し，著者が特に表現したい内容（主 題) を把握し，それを表す適切な索引語（ディス クリプタ, 副標目, チェックタグ (後述) ) を付
与する。

本稿では, 当会の索引および検索のツールであ る「医学用語シソーラス」を, 索引ルールや, デー タベース作成システムにおけるその活用にも触れ ながら紹介する。

\section{2. 医学用語シソーラス}

文献内容から重要な概念を抽出し，それを表す 索引語が，ディスクリプタ (見出し語) である。 「医学用語シソーラス」は，医学文献で扱われるさ まざまな主題（疾患名，治療法，解剖名，等）に 関するディスクリプタを，体系的にまとめたもの である。「医中誌Web」で提供しているデー夕の索 引は, この「医学用語シソーラス」に基づいて行 われる。

「医学用語シソーラス」は1983年に，それまで索 引誌で使用されていた件名をまとめた「医中誌索 引誌件名標目集」を基に，第1版が刊行された。 1994年発行の第3版より, 用語の収録範囲や力テ ゴリーの構成を, 米国国立医学図書館 (NLM) が 発行するシソーラスMedical Subject Headings (以下, MeSH）に準拠したものとした。その後2度の改訂 
を経て，2007年にMeSH2005に準拠した第6版を刊 行した(表1) ${ }^{2)}$ 。

\section{1 「医学用語シソーラス」の収録語}

「医学用語シソーラス」第6版には, 25,317語の ディスクリプタが収録されている。このうち $\mathrm{MeSH}$ 由来語は，22,647語 (MeSH2006，2007からも一 部収録）であり, MeSH2005の22,997語のうち約90 \%を収録している。

「医学用語シソーラス」には, これ以外に, 国内 医学で必要な2,670語も収録している。その内訳 は, 医薬品の国際一般名 (INN), 生薬名(「日本薬 局方」, 「日本薬局方外生薬規格1989増補版」より), 漢方処方名（JAPIC医薬品集より），日本の医療制 度に基づく用語（「介護保険」，「療養病床」等）, MeSHでは比較的登録の少ない看護に関する用語, 等である。種類別のディスクリプ夕数を表 2 に示 す。これらは, MeSHのTree Numberを基に作成した カテゴリーコードに枝番を追加する方法で位置づ けた。

なお，MeSH2005収録語のうち，第6版には採用 しなかったものが548語ある。国内医学では必要性 が低いと判断したもので，その内訳は，アメリカ の医療制度に基づく用語（“Blue Cross”，等），アメ リ力の地名, 歴史的事件の用語（“September 11 Terrorist Attacks”, 等), Publication Characteristics (出 版特性: 医中誌Webでは, 論文種類, 研究デザイ ンタグなどが相当する), 等である。

\section{2 収録語の関連づけ}

「医学用語シソーラス」では, 索引・検索におい て，適切なディスクリプタを見いだしやすいよう に，用語間およびディスクリプタ間を関連づけて いる。以下に，それらの関連づけについて説明す る。

\subsection{1 ディスクリプタと同義語}

「医学用語シソーラス」では，同じ概念を表す用 語が複数ある場合, 索引や検索に優先して使用す る用語をディスクリプタとして示し，それ以外の 用語を同義語として関連づけている。

\section{表2 医中誌独自収録語内訳}

\begin{tabular}{|c|c|c|}
\hline \multirow{2}{*}{$\begin{array}{l}\text { 内 訳 } \\
\text { 国際一般名 (INN) }\end{array}$} & \multicolumn{2}{|c|}{$\begin{array}{c}\text { ディスクリプタ数 } \\
\text { ( )内は新設語 }\end{array}$} \\
\hline & 1,666 & (262) \\
\hline 漢方薬 & 148 & (1) \\
\hline 生薬 & 169 & (74) \\
\hline 地名 & 90 & (90) \\
\hline 看護·介護 & 70 & (5) \\
\hline 日本独自の制度·機関 & 97 & (19) \\
\hline 解剖名 & 42 & (8) \\
\hline 生物名 & 11 & (8) \\
\hline 疾患名 & 101 & (3) \\
\hline 物質名 & 40 & (0) \\
\hline 診断·治療の手技 & 100 & (8) \\
\hline その他 & 136 & (8) \\
\hline 合計 & 2,670 & (486) \\
\hline
\end{tabular}

表1「医学用語シソーラス」各版概要

\begin{tabular}{|l|c|c|c|c|c|c|c|}
\hline \multicolumn{1}{|c|}{ 版 } & 第1版 & 第2版 & 修正版 & 第3版 & 第4版 & 第5版 & 第6版 \\
\hline 発行年 & 1983 & 1987 & 1990 & 1994 & 1999 & 2003 & 2007 \\
\hline 準拠したMeSH & 1978 & 1984 & 1984 & 1991 & 1997 & 2001 & 2005 \\
\hline ディスクリプタ数 & 13,485 語 & 17,882 語 & 17,926 語 & 14,454 語 & 18,156 語 & 21,378 語 & 25,317 語 \\
\hline 最深カテゴリー & 3階層 & 4階層 & 4階層 & 7階層 & 11階層 & 12階層 & 12階層 \\
\hline 医中誌DBの主な提供媒体 & 冊子体 & 冊子体 & 冊子体 & CD-ROM & CD-ROM & Web & Web \\
\hline
\end{tabular}


当会の用語管理のシステムには，ディスクリプ 夕に対応した約30万語の同義語を登録している。 例えば，医薬品では，国際一般名（INN）のアル ファベット表記をディスクリプタとし，カタカナ 表記, 商品名, 化学名, 治験番号を同義語として 登録している（表3）。多数の同義語をディスクリ プタと関連づけることにより，利用者が思いつい た用語からディスクリプタに到達できるように なっている。

なお，「医中誌Web」の検索では，入力した語が 同義語辞書に登録されている語と一致した場合, ディスクリプタに自動的に案内されるマッピング 機能が働き，シソーラスを意識しなくても，モレ の少ない検索が可能となっている。

シソーラスに基づき人手で行う索引の大きな特 長は，個々の文献では，さまざまに表現される1つ の概念に対して，統一したディスクリプタを付与 することで，これらを網羅的に検索できることで ある。例えば，文献で“胃癌”，“胃がん”，“胃悪 性腫瘍” 等さまざまな表現で記載されていても,す ベてディスクリプタである「胃腫瘍」を付与する。 さらに“胃に原発した癌”というように，1つの単 語として表現されていない場合でも，索引者はそ

\section{表3「Atorvastatin」の同義語}

\begin{tabular}{|l|}
\hline Atorvastatin Calcium \\
\hline Atorvastatin Calcium Hydrate \\
\hline Atorvastatin, Calcium Salt \\
\hline CI-981 \\
\hline Lipitor \\
\hline Liprimar \\
\hline YM-548 \\
\hline アトルバスタチン \\
\hline アトルバスタチンカルシウム \\
\hline アトルバスタチンカルシウム水和物 \\
\hline アトロバスタチン \\
\hline リピトール \\
\hline
\end{tabular}

こに記載されている概念に対して，「胃腫瘍」を付 与する。反対に，“胃癌以外の”というように，“胃 癌”という単語が含まれていても, 胃癌について 述べられていなければ,「胃腫瘍」は付与しない。 このように，索引者による文献内容に応じたディ スクリプタの付与により, 単なる文字列検索では なし得ない，適切で網羅的な検索が可能になって いる。

\subsection{2 カテゴリーコード}

「医学用語シソーラス」では, ディスクリプタを 15のカテゴリーに分類し（表4），概念の広さを階 層づけするために，ディスクリプタごとにユニー クなカテゴリーコードを付与している。

そして，ディスクリプタの概念に，複数の観点 からみた分類がある場合, 複数のカテゴリーコー ドを付与している。例えば，「AIDS」には，感染経 路からみた分類，発症まで長い潜伏期間を持つと いう特徵からみた分類, 病原微生物の生物分類か

$$
\text { 表4 第6版カテゴリー別ディスクリプタ数 }
$$

\begin{tabular}{lrr}
\hline & \multicolumn{2}{c}{ ディスクリプタ数 } \\
カテゴリー & \multicolumn{2}{c}{ ( )は新設語 } \\
\hline A: 解剖学 & 1,483 & $(102)$ \\
B: 生物 & 3,543 & $(1,795)$ \\
C: 疾患名 & 4,212 & $(205)$ \\
D: 化学物質および薬物 & 9,646 & $(1,286)$ \\
E: 分析, 診断, 治療の技術と機器 & 2,321 & $(204)$ \\
F:精神医学 & 87 & $(59)$ \\
G:生物科学 & 2,064 & $(192)$ \\
H: 自然科学 & 529 & $(40)$ \\
I: 人類学, 教育, 社会学, 社会現象 & 486 & $(59)$ \\
J: エ業技術, 産業, 農業 & 351 & $(41)$ \\
K: 人文科学 & 149 & $(43)$ \\
L: 情報科学 & 367 & $(36)$ \\
M: 人間集団 & 197 & $(31)$ \\
N: 保健医療サービス & 1,146 & $(100)$ \\
Z: 地理的位置 & 304 & $(303)$ \\
\hline ※複数カテゴリーを持つディスクリプタがあるため, カ \\
テゴリー別のディスクリプタ数の合計は, 実際の語数 \\
よりも多くなつている。
\end{tabular}




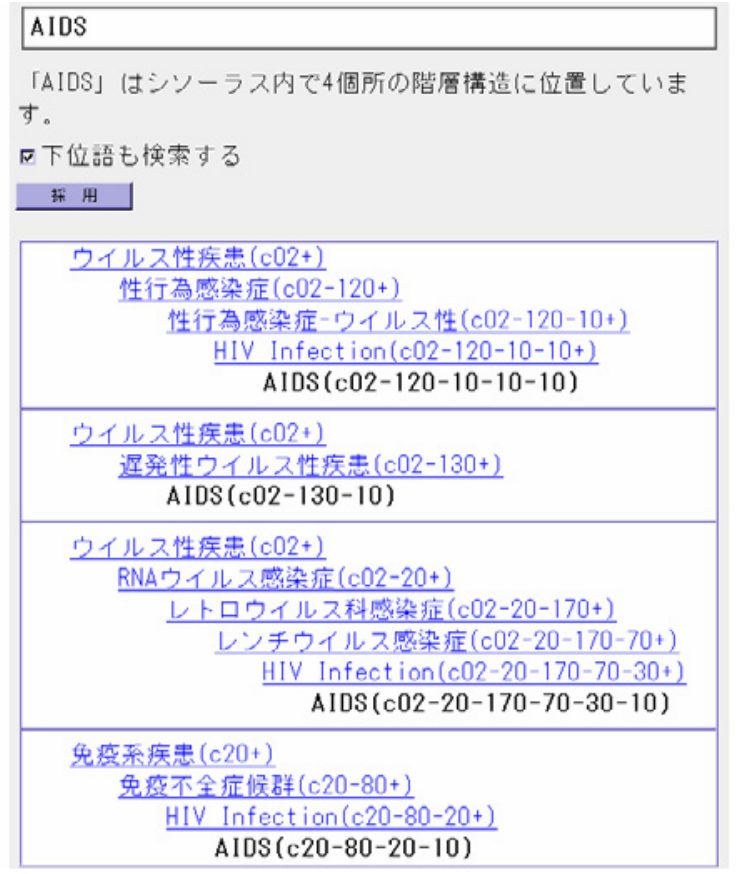

図1「AIDS」のカテゴリー

らみた分類, 免疫不全という症候としての分類と いう4つの観点からカテゴリーコードが付与され ている(図1)。

これらのカテゴリーコードにより，上位概念と して示されている属性が, 下位概念のディスクリ プタに付加されている。病原微生物の生物分類の カテゴリーを例にとると,「AIDS」には,「ウイル ス性疾患」,「RNAウイルス感染症」,「レトロウイ ルス科感染症」,「レンチウイルス感染症」,「HIV Infection」のすべてが属性として付加されている。 このように, 多面的で詳細なカテゴリーコードが 付与されているため, ディスクリプタの持つさま ざまな属性を，検索の中で活用することができる のである。具体的には，「医中誌Web」の「下位語 も含む」検索において，このカテゴリーコードを 活用し, ディスクリプタの概念の広さに応じて, そ こに含まれる下位語も併せて検索される。

ただし、「AIDS」はすべて「HIV Infection」である が, 必ずしも「性行為感染症」ではない。このよ うに上下関係にあっても，上位概念の中に下位概
念がすべて包含されている場合と，上位概念の属 性が下位概念のすべてに該当するわけではない場 合とが，混在している。これは，多少ノイズが含 まれても, 網羅的に検索されることが有用と判断 したものを下位語に位置づけているためである。 例えば，個別の薬物名には，(化学物質としての力 テゴリーに加えて）薬効別のカテゴリーを付与し ているが，これは，ある薬効を持つ薬物が網羅的 に検索できることを優先したためである(MeSHで は1996年より，薬効別のカテゴリーの下位に個別 の薬物を位置づけることをやめ, 薬効のディスク リプタを併せて付与する方針に変更されたため, 医中誌独自の処理である $\left.{ }^{3)}\right)$ 。

反対に，ノイズが含まれないように下位語から 外す場合もある。例えば,「多施設共同研究」は, 第5版では，「臨床試験」の下位に位置づけられて いたが，第6版から「臨床試験」の下位から外し， より上位概念の「疫学的研究特性」の下位語に変 更した。「多施設共同研究」は，臨床試験だけでな くコホート研究などの疫学的研究にも付与される ため,「臨床試験」の下位語も含む検索の際に，ノ イズが含まれないよう考慮したためである。なお, 大規模臨床試験など，多施設で行われる臨床試験 は,「多施設共同研究」と「臨床試験」およびその 下位語とを併せて付与する方針に変更し，過去の 索引データのメンテナンスも行った。

\subsection{3 関連参照語}

「医学用語シソーラス」では, 階層関係にはない が，関連の深いディスクリプタを，「関連参照語」 として掲載している。これは「医中誌Web」の検 索では，今のところ活用されていない。ディスク リプタの関連関係をどのように提示していくの か, その必要性も含め, 今後の検討課題である。 


\section{3. 医中誌フリーキーワード}

索引では,「医学用語シソーラス」の中から, ディ スクリプタを選択して付与するのが原則である。 ただし、「医学用語シソーラス」に登録されていな い概念でも, 索引上重要とみなされるものは,「医 中誌フリーキーワード」として随時登録し, 必要 に応じて付与している。個別の文献では重要な概 念でも, 全体からみると頻度が低いものや, 蛋白 質などの物質名は膨大な数があるため,「医中誌 リーキーワード」として運用している。2008年9 月現在で, 約3万語が登録されている。

「医中誌フリーキーワード」のうち, 頻度が高く, 有用性が高いと判断されたものは, 改訂時に, シ ソーラスのディスクリプタとして収録されること もある。

\section{4. 副標目}

ディスクリプタと組み合わせて付与するもの で，そのディスクリプタが文献中でどのような観 点で扱われているかを示す。MeSHの “Subheadings” (“Qualifier”とも呼ぶ) にあたるもので，35個ある 副標目のうち, MeSHと共通のものは32個,「精神
療法」，「予後」「実験的」の3個は，医中誌独自の 副標目である。ある薬物が治療に使用されている のか，その毒性や副作用について述べられている のか等, 1つのディスクリプタでも文献によって, 扱われている観点が異なる。適切な副標目をディ スクリプタに併せて付与することで，より詳細な 検索二ーズに応えることができる。

副標目は，ディスクリプタのカテゴリーによっ て, 付与可能かどうかが決められている。薬物（D カテゴリー）による有害事象であれば，副標目は 「毒性・副作用」を付与し, 手技名（E力テゴリー） に付与する「有害作用」や, 疾患名 (C力テゴリー) に付与する「合併症」は付与しない (表5)。 ただし，副標目の付与について，例外的な扱い をしている場合がある。ディスクリプタの意味の 中に, 副標目の内容がすでに含まれている場合, そ の副標目は重ねて付与しない。例えば,「薬疹」に 副標目「化学的誘発」, あるいは「血糖」に副標目 「血液」は付与しない。反対に副標目を付与するこ との有用性が高いと判断したものは，該当する力 テゴリーでなくとも付与可能としているものがあ る。例えば，F1カテゴリーの「抑うつ」は，カテ ゴリーからみると副標目は付与できないことにな るが，疾患と同様に治療や診断が行われることも

表5 副標目一覧表（ )内は付与可能カテゴリー

\begin{tabular}{|c|c|c|c|c|}
\hline 薬物·化学物質に関する副標目 & 診断に関する副標目 & 治療に関する副標目 & 疾患の原因などに関する副標目 & その他 \\
\hline $\begin{array}{l}\text { 薬理学（B6※, D ) } \\
\text { 毒性·副作用（B5\%, B6\%, D, J2※) } \\
\text { 治療的利用（B5\%, B6\%, D, H, J2※) } \\
\text { 診断的利用 (D) } \\
\text { 類似体·誘導体（D） } \\
\text { 拮抗物質·阻害物質（D） } \\
\text { 血液（D） } \\
\text { 尿（D） }\end{array}$ & \begin{tabular}{|l}
$\mid$ 診断（C, F3※） \\
画像診断（A, C, F3※） \\
X 線診断（A, C, F3※） \\
放射性核種診断（A, C, F3※) \\
超音波診断（A, C, F3※） \\
病理学（A, C, F3※）
\end{tabular} & 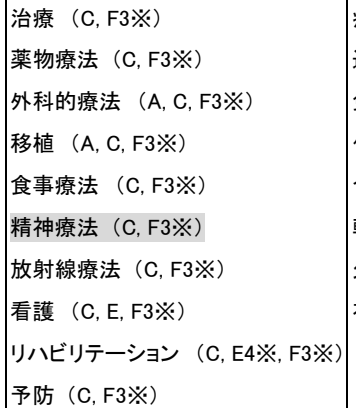 & $\begin{array}{l}\text { 病因 }(C, F 3 ※) \\
\text { 遺伝学 (C, F } 3 \text { ) } \\
\text { 免疫学 (C, F3※) } \\
\text { 化学的誘発 (C, F3※) } \\
\text { 合併症 (C, F } 3 ※) \\
\text { 転移性 (C4※) } \\
\text { 欠損·欠乏 (D) } \\
\text { 有害作用 }(E, H)\end{array}$ & $\begin{array}{l}\text { 疫学 (C, F3※) } \\
\text { 予後 (C, F3※) } \\
\text { 実験的 (C, E, F3※) }\end{array}$ \\
\hline
\end{tabular}

※ B5：真菌, B6 : 植物, C4：腫瘍, E4 : 外科手術, F3 : 精神障害, J2 : 食品と飲料 
多いので,「薬物療法」等の疾患名に付与する副標 目を付与可能としている。また, 文献で予防とい う観点で扱われることが多い「自殺」には，副標 目「予防」を付与可能としていることなどがあげ られる。

\section{5. チェックタグ}

文献の内容を特徵づけるいくつかの観点を示す もので，以下のものがある。

文献に書かれた対象の属性を表すタグとして, 「ヒト」, 「動物」, 動物の種類（「マウス」，他），年 齢区分 (「新生児」, 他), 性別, 「娃娠」がある。

研究デザインを表すタグとして,「メタアナリシ ス」,「ランダム化比較試験」,「準ランダム化比較 試験」「「比較研究」(以上は原著論文に付与),「診 療ガイドライン」(解説文献に付与) がある。なお, 文献で実際にその研究デザインが用いられている 場合には, タグと重ねて該当の研究デザインの ディスクリプタを付与するが, その研究デザイン を説明するなど，主題として論じられている場合 には，ディスクリプタのみを付与する。

他に，文献の分類を表す夕グとして，「看護」， 「歯学」,「獣医学」があり, これらの専門分野の文 献に付与する。

これらのタグは「医中誌Web」で, 検索対象を 絞り込むために用いられる。

\section{6. 索引ルール}

索引の目的は, 文献検索において利用者が必要 とする文献に，的確に効率よくたどり着くことで ある。そのためには文献内容を正確に表現し，索 引者による個人差の少ない均質な索引がされなけ ればならない。当会では, 膨大な文献をすべて人 手により索引するので, 多数の索引者が索引作業
を行っている。そのため, 索引の均質性, 一貫性 には特に注意が払われ，索引についての全般的な 原則から，ディスクリプタごとの注意点まで多数 のルールが定められている。このうち主な原則を 以下に述べる。

\section{1 正しいディスクリプタの選択}

ディスクリプタは，シソーラスで定められた定 義に基づき使用される。例えば“中高年のコン ピュータアレルギー” (心理的な拒否反応の意) と 記載された文献について，「医学用語シソーラス」 で免疫疾患として位置づけられている「アレル ギー」は付与しない。

\section{2 特定性の高いディスクリプタの選択}

索引したい概念の表す広さに対して，カテゴ リー階層上最も適合した（特定性の高い）ディス クリプタを選択する。文献タイトルに“糖尿病”と 記載されていても, 本文に記載されている内容が, 2型糖尿病に関するものであったら，下位語の「糖 尿病-2型」を付与する。概念の広さがぴったり一 致したディスクリプタが無い場合, 階層上最も近 い上位のディスクリプタを付与する。

\section{3 組み合わせによる索引}

索引したい概念と同じ意味のディスクリプタが 無い場合, ディスクリプタと副標目，あるいはディ スクリプタとディスクリプタを組み合わせること で，それを表すものがある。例えば，“転移性肝癌” は, 「肝茞腫瘍」十副標目「転移性」を付与する。 「腫瘍転移」というディスクリプタもあるが，これ は，「腫瘍転移」という現象を，特に取り上げて論 じている場合に付与する。 
ディスクリプタとディスクリプタの組み合わせ のパターンには, 部位名十疾患名, 病原微生物名 十疾患名などがある。例えば“膝窝静脈血栓症” は,「膝窩静脈」十「静脈血栓症」を, “O-157感染 症” は, 「Escherichia coli O157」十「大腸菌感染症」 を付与する。

腫瘍の索引は, 組み合わせによる索引の典型的 なものである。どこに発生したかを示す部位別の 腫瘍のディスクリプタと, 組織型のディスクリプ 夕を組み合わせて付与する。例えば胃に発生した 平滑筋肉腫であれば, 「胃腫瘍」と「平滑筋肉腫」 を付与する。

以上，索引に関する原則のうち主なものを述べ た。

当会で定めた多数のルールが,「インデクシング マニュアル」としてまとめられ，索引者はこのマ 二ュアルに則して索引する。索引ルールの理解を 深めるために，研修会を定期的に開催するなどし て，索引の質の向上が図られている。

なお，インデクシングマニュアルは，近々，当 会ホームページで，公開予定である。

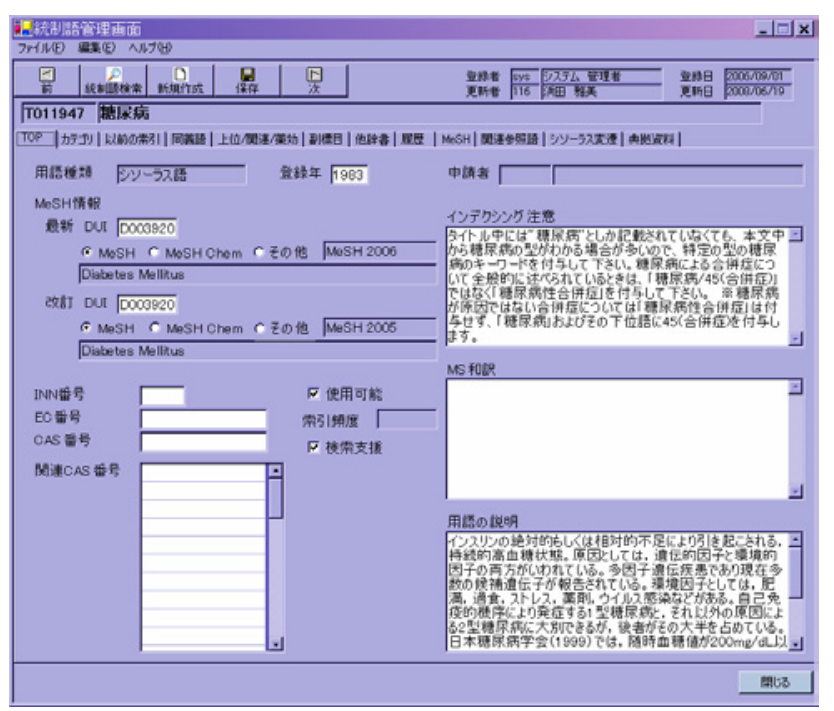

URL: http://www.jamas.or.jp/index.htm

\section{7. データベース作成システムにおける索 引支援機能}

当会では，1996年に編集工程の○A化を実施し， 「医中誌Web」に収録するデータの作成を，すべて 会内LAN上に構築されたデータベース作成システ ムにて行うようになった。索引デー夕作成は，実 際に索引作業を行う「索引作業画面」と，ディス クリプタに関する情報を管理する用語管理のシス テムにより行われる。

このシステムは，シソーラスの改訂に合わせて バージョンアップが行われ，2006年12月より，第 6 版シソーラスデータを搭載した新しいシステム による索引作業が開始された。新システムにおい ては「索引の質の維持」と「効率性」という, と もすれば相反することとなりかねない2点の両立 を目的に，索引支援機能を充実させた。以下に，用 語管理のシステムと「索引情報画面」および索引 支援機能の概要を紹介する4)。

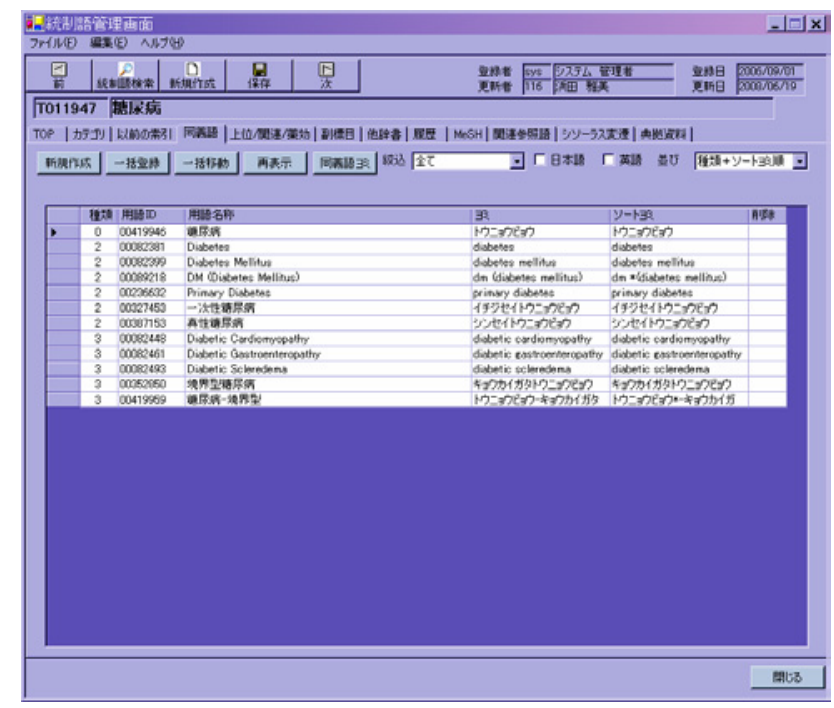

図2 用語管理のシステム「TOP」画面と「同義語」画面 


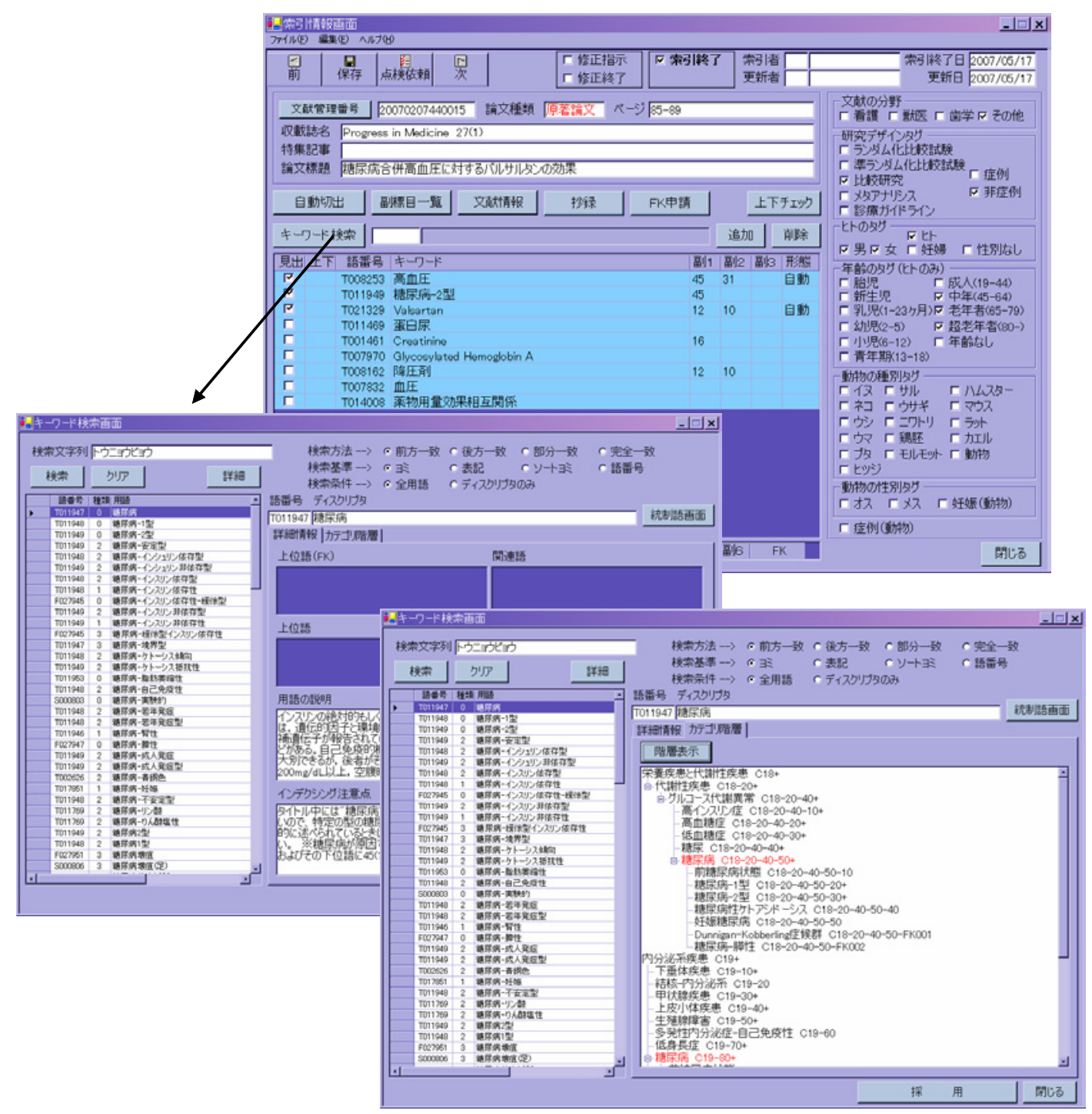

図3「索引情報画面」と「キーワード検索画面」

\section{1 用語管理のシステム}

用語管理のシステムでは，1つのディスクリプタ とその同義語からなる概念のまとまりに対して, ユニークなD番号を付与することで, ディスクリプ 夕と同義語の関連づけを行っている。1つのID番号 内には, ディスクリプタ, 同義語, カテゴリーコー ド, 用語の説明, インデクシング注意, 典拠情報, 付与可能副標目など，ディスクリプタ（概念）に 関する情報が登録され, 必要に応じて随時, 追加・ 変更・削除が行われている(図2)。ここで編集さ
れた内容が，後述する「索引情報画面」の「キー ワード検索画面」に表示される。

\section{2 「索引情報画面」}

「索引情報画面」には，1つの文献について書誌 事項，抄録が表示され，索引者は，手元にある雑 誌の文献に目を通しながら，内容に合ったディス クリプタ, 副標目, チェックタグを, その画面の 該当する箇所に入力していくことにより，索引作 業を行う(図3)。付与されたタグ同士の整合性や, 
付与されたディスクリプタについて用語管理のシ ステム内に登録されている情報を参照し，エラー メッセージを出すなどの索引支援機能が搭載され ている。

\section{3 キーワード検索画面}

ディスクリプタの付与は，「索引情報画面」の 「キーワード検索画面」で用語の検索を行い, そこ に表示されたディスクリプタを選択し「採用」す ることによって行われる。この「キーワード検索 画面」には，索引に必要な情報が集約されて表示 されている(図3)。

\section{4 同義語からの案内}

先に述べたように, 多数の同義語を登録してい るため, 文献中に出現した用語や思いついた言葉 から検索して, 統制先のディスクリプタに到達す ることができる。

\section{5 カテゴリーの表示}

「キーワード検索画面」から, カテゴリーの階層 構造を表示させることができる。この機能により， 文献内容に合致した特定性の高いディスクリプタ の選択や，上位概念の確認などが容易にできる。

\section{6 付随情報の表示}

「キーワード検索画面」に，ディスクリプタの意 味を示す「用語の説明」と, 索引ルールに基づい た付与基準を示す「インデクシング注意点」を表 示し，ディスクリプタの正しい選択を支援してい る。

\section{7 索引支援語}

先に述べたように, 腫瘍は, 部位別の腫瘍のディ スクリプタと, 組織型のディスクリプタを組み合 わせて付与するが，このように複数のディスクリ プタの組み合わせが決まっているものを,「索引支 援語」として登録している。例えば，索引支援語 として「胃平滑筋肉腫」が登録されており, これ を選択すると「胃腫瘍」と「平滑筋肉腫」の2つの ディスクリプタが付与される。

なお，「索引支援語」は，「医中誌Web」の検索 においては，「検索支援語」として活用され，“胃 平滑筋肉腫”と入力すると, 「胃腫瘍」と「平滑筋 肉腫」で，下位語を含まない掛け合わせ検索（and 検索）が自動的に行われる。

\section{8 副標目およびチェックタグの付与ミス防止}

先に述べたように，副標目はディスクリプタの カテゴリーによって, 付与可能かどうかが決めら れているが，用語管理のシステム内では，よりき め細かい対応が可能になるよう, 個別のディスク リプタごとに付与可能な副標目を設定している。 例えば前述した「自殺」には，「予防」のみを付与 可能副標目として設定している。これにより，索 引の際に, あるディスクリプタに対して付与可能 としていない副標目が付与されたとき，エラー メッセージが出て保存ができないようにし，付与 ミスを減らしている。

また, チェックタグの付与モレ防止のために, 例 えば，症例報告文献では，年齢，性別の夕グが付 与されていないと, 注意を促すメッセージが出る 等, さまざまな工夫がされている。 


\section{9 タイトルからのディスクリプタ抽出}

バッチ処理にて, 文献タイトル中の言葉を切り 出し，それがディスクリプタあるいはその同義語 に一致した場合には，自動的に該当のディスクリ プタが付与される仕組みがある。1996年のOA化当 時に開発され, その後, 精度を上げる改良が加え られている。この「前処理」により, 索引作業の 効率化が実現した。索引者は自動的に付与された ディスクリプタの適否を判断し，不適切な場合に は削除し，不足しているディスクリプ夕を追加す る。

索引上有用でない用語は, 用語管理のシステム 内で, 自動付与されないような処理を行っている。 アルファベット, ひらがな, カタカナで3文字以 内, 漢字1文字といつた文字数の少ない用語は, 不
適切に切り出されてしまうことが多い。例えば, “肝右葉”から，植物の「葉」が切り出されてしま う。また,「治療」、「腫瘍」などは, 概念として大 き過ぎ，実際の索引には下位語を付与した方が適 切な場合が多い。このような用語は, 自動付与さ れない処理の対象となる。

\section{8. まとめ}

索引における「医学用語シソーラス」の役割を 中心に，当会の索引ルールや，データベース作成 システムにおける索引支援機能についても紹介し た。今後,「医学用語シソーラス」の情報を, 利用 者にとってより利用しやすい形で開示していくこ とが望ましいと考えている。利用者の方々に広く 活用していただけるよう検討してまいりたい。

\section{参考文献}

1）佐久間せつ子．医学中央雑誌データベースの特徵。薬学図書館. 2007, vol.52, no.2, p.124-130.

2) 浜田雅美. 医学用語シソーラスの改訂。薬学図書館. 2007, vol.52, no.4, p.358-367.

3) シソーラス研究会。“MeSH情報 PubMed検索での薬理作用関係のMeSH索引の変更”。医学用語を歩 $<$ !. http://homepage3.nifty.com/sisoken/, (参照2008-09-26).

4) 白土裕子。医学中央雑誌データベース作成システム (JAMAS2システム) について。医中誌News. 2007, no.5, p.2-5.

\section{著者抄録}

「医中誌Web」は, 国内で発行される医学およびその関連分野の定期刊行物 2,500 誌以上に掲載される文献情 報を収録するデータベースであり，2000年よりサービスが開始された。収録文献数は，年間30万件以上で， 現在650万件を超えている。各文献には，専門の索引者が「医学用語シソーラス」に基づき，主題にふさわ しいディスクリプタ (見出し語) を付与している。「医学用語シソーラス」は,「医中誌Web」の索引およ び検索のツールであり，米国医学図書館が作成するMedical Subject Headings (MeSH) に準拠して作成されて いる。1983年発行の第1版から何度かの改訂をへて，MeSH2005年版に準拠した第6版が，2007年1月に発行 された。第6版には，25,317語のディスクリプタが収録され，それに関連づけられた30万語以上の同義語 が，用語管理システム内に登録されている。これにより，索引の際の的確なディスクリプタの選択が容易 
になっている。さらに,「医中誌Web」において, シソーラスを意識せず的確な検索結果を得るための, ディ スクリプタへの自動マッピング機能に活用されている。本稿では,「医学用語シソーラス」に基づく索引 ルールや，医中誌データベース作成システムのうちの，索引支援システムについて紹介した。

キーワード

医中誌Web, 情報検索, シソーラス, 索引作成, データベース管理システム

\section{Author Abstract}

"Ichu-Shi Web" is the database that contains bibliographic citations and abstracts from more than 2,500 biomedical journals and other serial publications published in Japan. It was started in 2000. The number of citations is more than 300,000 per year and now exceeds 6.5 million. Trained indexers attach descriptors (controlled keywords) that are relevant to the subject contents of each article, based on the "Thesaurus for Medical and Health-Related Terms (Ichu-Shi Thesaurus)". We have edited and published the thesaurus as a tool for indexing and searching since 1983. The 6th edition based on the US National Library of Medicine's Medical Subject Headings (MeSH) 2005 has been published in January 2007. It contains 25,317 descriptors and more than 300,000 synonyms that are connected with each other (mapping) in the thesaurus management system. Using the system, indexers can easily find descriptors suitable to the article. Furthermore "Ichu-Shi Web" automatically performs descriptors search using a mapping feature, without referencing the thesaurus in advance. Here we described the current indexing rules of the Ichu-Shi Thesaurus and the indexing support function, a part of the total Ichu-Shi database processing system, which has been newly developed.

\section{Key words}

Ichu-Shi Web, information retrieval, thesaurus, indexing, database management system 